\section{DIGITAL COMMONS \\ @ UNIVERSITY OF SOUTH FLORIDA}

\section{ABO: Interactive Journal for Women in the Arts, 1640-1830}

Volume 10

Issue 2 Fall 2020

Article 3

2020

\title{
Review of the London Stage Database
}

Fiona Ritchie

McGill University, fiona.ritchie@mcgill.ca

Follow this and additional works at: https://digitalcommons.usf.edu/abo

Part of the Digital Humanities Commons, Feminist, Gender, and Sexuality Studies Commons, Literature in English, British Isles Commons, and the Theatre and Performance Studies Commons

\section{Recommended Citation}

Ritchie, Fiona (2020) "Review of the London Stage Database," ABO: Interactive Journal for Women in the Arts, 1640-1830: Vol.10: Iss.2, Article 3.

http://doi.org/10.5038/2157-7129.10.2.1242

Available at: https://digitalcommons.usf.edu/abo/vol10/iss2/3

This Digital Humanities is brought to you for free and open access by Digital Commons @ University of South Florida. It has been accepted for inclusion in ABO: Interactive Journal for Women in the Arts, 1640-1830 by an authorized administrator of Digital Commons @ University of South Florida. For more information, please contact digitalcommons@usf.edu. 


\title{
Review of the London Stage Database
}

\author{
Abstract \\ we think about eighteenth-century theatre.

\section{Keywords} \\ database, London stage, eighteenth-century theatre \\ Creative Commons License \\ (c) (1) (3)
}

The London Stage Database is an open-access and open-source website that digitises the performance records contained in the print volumes of the London Stage, published in the 1960s. The database's flexible search function and intuitive interface open up new directions in research and will change the way

This work is licensed under a Creative Commons Attribution-Noncommercial 4.0 License 
The London Stage Database. Mattie Burkert, et al. https://londonstagedatabase.uoregon.edu/.

Reviewed by Fiona Ritchie

McGill University

For fifty years, scholars of the eighteenth-century British theater have relied on the London Stage, an eleven-book reference work published in the 1960s, for details of performances that took place in the capital in the period 1660-1800. The records contained in these volumes have now been made available electronically in the London Stage Database, a project headed by Mattie Burkert. Searches that would previously have required a trip to the library and time spent leafing through the pages of multiple volumes can now be accomplished at home with a few mouse clicks. Best of all, the database is open access and open source, facilitating access for all without the need for a library subscription. I write this review as someone who is a reasonably competent user of technology but not a digital humanities scholar. I do, however, have a deep and longstanding scholarly interest in eighteenth-century theater history. I was a beta tester for the database before it launched and since that time have used it extensively in my research.

The London Stage Database's "About" page contains a detailed description of the origins of this electronic resource and the principles involved in developing it. Shortly after the print volumes were produced, a computerized database of the records contained in the reference work was commissioned in order to facilitate large-scale research. This database, known as the London Stage Information Bank, sadly became technologically obsolete after only a few years. With financial support from the National Endowment for the Humanities, Burkert has worked to recover the Information Bank after much of the data and code had been corrupted and to transform it into a freely available online resource. The project originated at Utah State University, with the assistance of developers Todd Hugie and Dustin Olson and research assistant Emma Hallock and is now hosted by the University of Oregon.

The "User Guide" contains a wealth of helpful information, including notes on Old and New Style dating, the limitations of cast lists, a brief discussion of how eighteenth-century theater goers understood the concept of authorship, and definitions of a number of key terms. The contextual material therefore offers a helpful introduction to the theater of the period, as well as a description of the technical aspects of the project. One element that might be added in future is a discussion of the site's accessibility for users with disabilities. 
The site's "Advanced Search" function is extremely flexible. Users can search, for example, for performances at a particular theater, stagings of specific plays, appearances of named actors in key roles, performances that occurred on or between certain dates, types of entertainment (dance, song, opera, ballet, etc., as well as the conventional mainpieces and afterpieces), and so on. Once results are generated, they can be sorted by relevance or date and further filtered using the same criteria from the "Advanced Search" page (venue, date, title, author, performance type, actor, role, keyword, etc.). On the event page for a particular performance, users can see the entire menu of entertainment offered that evening (mainpiece, afterpiece, and entr'acte entertainments) along with cast lists, as well as newspaper commentary and box office takings (where available), just as they would in the print edition of the London Stage. Indeed, a PDF of the relevant page from the print volume is reproduced here, as well as other phases of the data (the original electronic data from the Information Bank, as well as its cleaned and parsed iterations). Across the site, the user interface is clean, easy to use, and aesthetically pleasing.

Some eighteenth-century theater historians may be familiar with another digital version of the data from the London Stage presented by Adam Matthew Digital as part of their online resource Eighteenth Century Drama: Censorship, Society and the Stage. This is a paid product available through major research libraries, which encompasses many other documents in addition to the performance records, notably primary source materials such as the Larpent collection of plays. This resource provides a number of data visualizations (such as "Most Performed Works") and data associations (e.g. "Roles" and "Actors"), but the fact that the data is not presented in an open-access, open-source format means that an individual user's analysis of it is limited. In contrast, the London Stage Database allows the export of data for search results or individual events in a variety of formats (CSV, XML, JSON) to enable further analysis and visualization. For the more technologically savvy, the "Toggle Query" button at the top of the search results page can be used to show how the search was translated into the database programming language SQL (Structured Query Language) and the entire dataset (that is, all of the information contained in the database) can be downloaded for personal exploration.

The website is upfront about the limitations of the damaged and incomplete data contained in the original Information Bank files and about the gaps in the London Stage's performance records that scholars have acknowledged in the past. In exploring the site, I have noted some minor quirks occasioned by these limitations. For example, the boxes on the search page will often automatically populate, which can be both helpful and confusing. In entering the play titled The 
Count of Narbonne, two autofill suggestions appear, "The Count of Narbonne" and "At Hay The Count of Narbonne," each of which yields a slightly different set of results. Both sets of results contain performance records of plays other than The Count of Narbonne: the first yields 49 hits, 37 of which are for the play in question with the remainder for other plays that feature "Count" in the title (The False Count and The Count of Burgundy); the "At Hay" search returns 164 results, only 37 of which are performances of The Count of Narbonne (including the one at the Haymarket Theatre that presumably generated this autofill), with other records that mention "Count" or simply "Hay." Searching for "The Count of Narbonne" produces the 37 recorded performances of that play that I was expecting. Conventional library search queries therefore seem to work better than the autofill options that may appear in some cases.

Another oddity occurs in regard to the names of actresses in the database. This will be of interest to readers of $A B O$ who intend to use the database for research into women's involvement in eighteenth-century theater. Clicking on the name of Miss Younge, the original Hortensia, in the cast list for the first performance of The Count of Narbonne on 17 November 1781, does not bring up a list of that actress's stage appearances, as we might expect, but rather a list of performances apparently by any woman billed as "Miss" (27,786 results for the period 1685 to 1800).

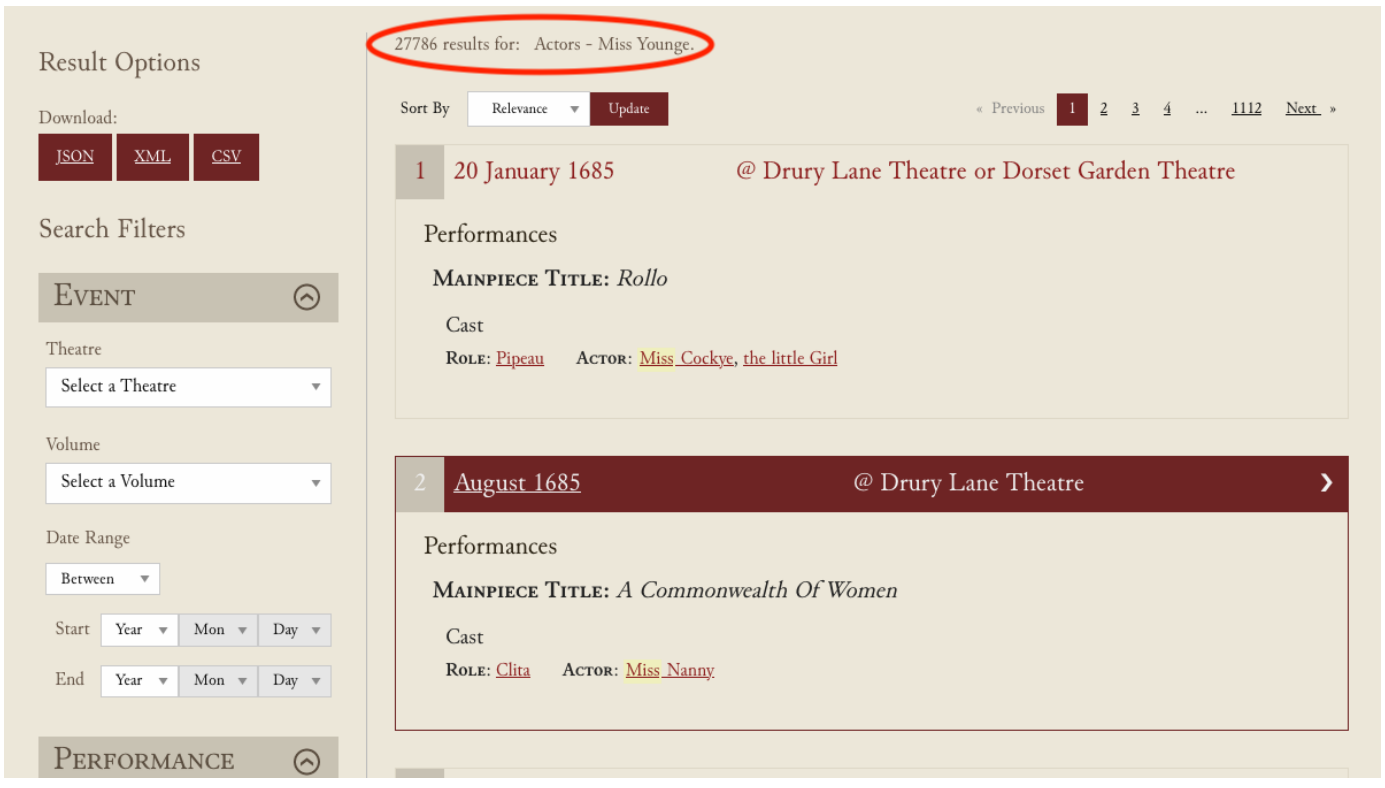

The same thing happens when I click on Mrs. Morton in the same cast list (36,995 results apparently of any actress billed as "Mrs" from 1661 to 1800). This issue 
seems to arise not (or not entirely) from the patriarchal naming practices of the eighteenth century, as I originally suspected, but from the persistence and, indeed, further entrenchment of such practices in the editing of the print volumes in the 1960s. On the original playbills, actors were recorded as "Mr," just as actresses were identified as "Miss" or "Mrs." But the editors of the London Stage envisaged the male performer as the default and recorded actors with their last names only (no "Mr" required). This makes accessing further information about male performers in the database much more straightforward because, unlike the women, they are not all lumped together under an honorific aimed at designating their sex and marital status. Clicking on Henderson's name in the same Count of Narbonne cast list brings up records of his other appearances, although included with these are references to another performer of the same name who appeared on the stage after the death of the John Henderson with whom we are concerned.

In order to track down the rest of Elizabeth Younge's recorded performances a few further steps are necessary. Typing "Miss Younge" (in quotation marks) into the Actor search box yields 980 hits for the period 1739 to 1785. Elizabeth Younge is probably the Miss Younge billed as appearing onstage for the first time as Jane Shore on 24 November 1768 (performance number 56 of the 980 results), and this is borne out by cross-referencing with another key source, the Biographical Dictionary of Actors, Actresses, Musicians, Dancers, Managers and Other Stage Personnel in London, 1660-1800 (the sixteen volumes of which are now available online through HathiTrust, thanks again to Burkert's efforts). Limiting the date range by entering a starting year of 1768 reduces the number of hits to 925 performances by Elizabeth Younge, the last of which took place on 27 May 1785. 


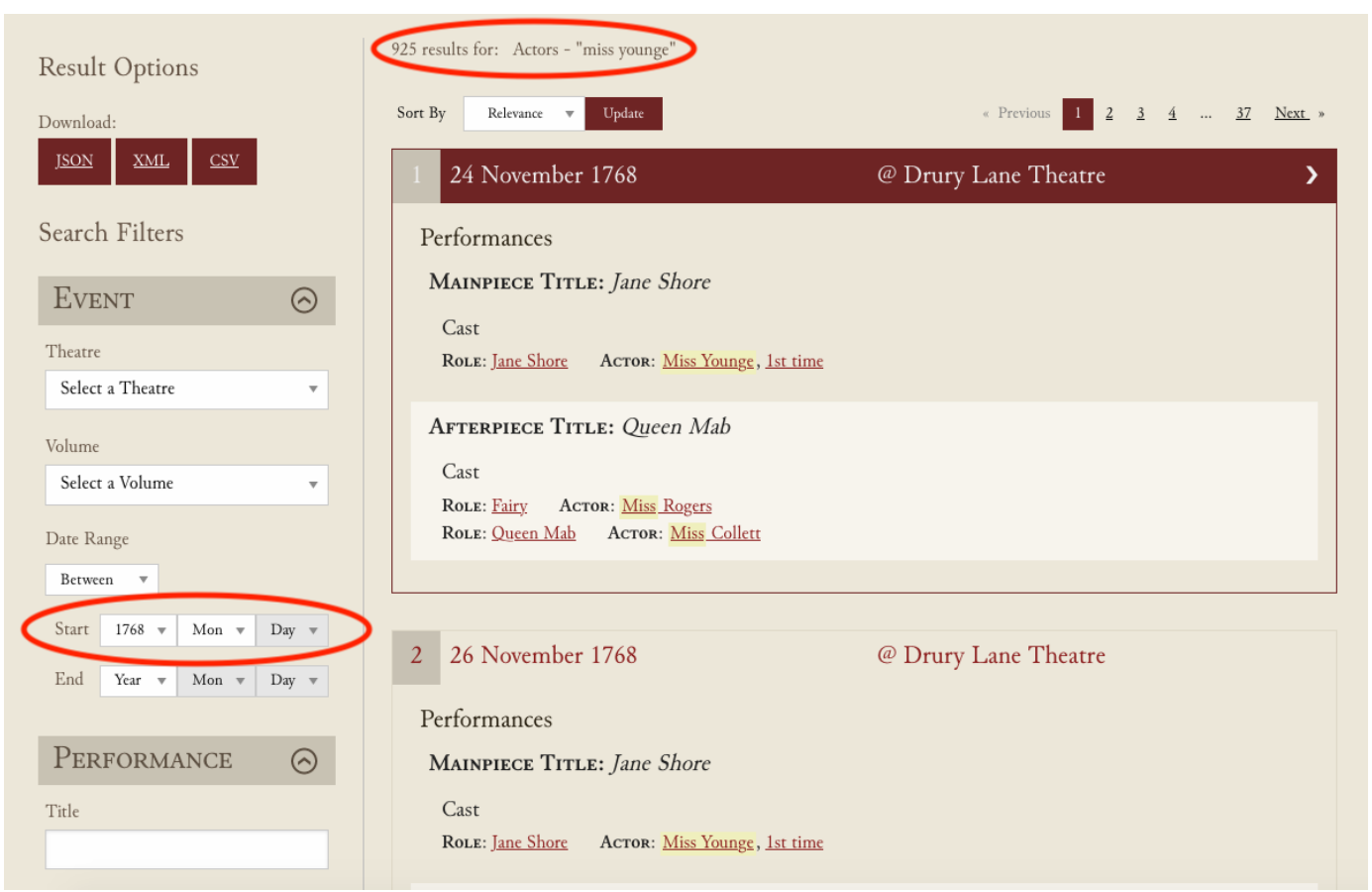

However, the Biographical Dictionary tells us that this actress made her final stage appearance on 26 January 1797, and in fact she is included in that reference work under her married name of Mrs. Alexander Pope. In order to capture all of the performances given by this actress on the London stage we must therefore also search the database for "Mrs Pope" with a date range of 9 August 1785 (when she married) to 26 January 1797. This yields an additional 835 results, bringing the total number of recorded performances given by Elizabeth Younge Pope to 1,760 over a thirty-year career (an average of 59 per season). ${ }^{1}$ I assume that, with additional time and funding for the project, these issues surrounding actresses' names could be addressed with further manipulation of the original code to separate out the individual actresses billed as "Miss" or "Mrs," to differentiate between multiple performers with the same last name, and to link appearances under maiden and married names. But the example of Elizabeth Younge Pope reveals some of the difficulties scholars interested in women's role in theatre history might face in their research as a result of both the limitations of the original data and restrictive attitudes to gender inherent in both eighteenth-century performance records and mid-twentieth-century scholarship. These issues also identify an avenue for future feminist digital research.

Some innovations have been made to the Information Bank data, and these are noted on the "About" page. Perhaps the most useful is the authorship information that has been added. One particular advantage of this is the list of "Related 
Works" that now appears on the event page for some performances. For example, the earliest recorded performance of The Tempest on 7 November 1667 notes that the play was adapted by John Dryden and William Davenant, and the "Related Works" include the Shakespeare text on which this version was based and subsequent adaptations by Shadwell, Garrick, and Kemble. This work is, as noted by the team, still in progress, but it has the potential to be particularly useful to those interested in adaptation in the period. The London Stage Database team are responsive to feedback and corrections and an email link and contact form are provided on the website for this purpose.

The London Stage Database has already achieved recognition outside the academy, featuring in an article in the Economist (26 October 2019) on Shakespeare's popularity in the period. But this resource facilitates research into areas beyond the Bard, including so-called minor forms of entertainment. While modern audiences may assume that Shakespeare was what drew playgoers to the theater, in many cases the spectacular afterpieces that followed his works were in fact what brought in customers. Furthermore, an evening at the theatre often included songs, entr'acte dances, and incidental music, which are now searchable here by filtering by performance type. The database makes visible the whole show on the eighteenth-century London stage and encourages us to rethink our assumptions about theater in the period by considering types of entertainment other than spoken-word drama, venues other than the two patent theatres of Drury Lane and Covent Garden, and performers other than famous stars. The London Stage Database is a major achievement that offers new directions in research and will change the way we think about eighteenth-century theater.

\footnotetext{
${ }^{1}$ In fact limiting the date range by year only (1785 to 1797) and not month and day as well brings up 844 hits, the last nine of which are performances billed as featuring "Miss Mansel in place of Mrs Pope" since the actress became so ill that she was unable to finish the season and hence was replaced. Elizabeth Younge Pope died on 15 March 1797.
} 